\title{
Recurring Events of Candida krusei Septicaemia: First Report from an ICU
}

\author{
Shalini Dewan Duggal, ${ }^{1}$ Pragnya Paramita Jena, ${ }^{1}$ Renu Gur, ${ }^{1}$ Avinash Kumar, ${ }^{1}$ \\ Sharon Rainy Rongpharpi, ${ }^{1}$ Mrignayani Pandey, ${ }^{2}$ Immaculata Xess, ${ }^{2}$ and Vineeta Wadhwa ${ }^{3}$ \\ ${ }^{1}$ Department of Microbiology, Dr. Baba Saheb Ambedkar Hospital, Rohini, Delhi 110085, India \\ ${ }^{2}$ Department of Microbiology, All India Institute of Medical Sciences, Delhi 110029, India \\ ${ }^{3}$ Department of Pediatrics, Dr. Baba Saheb Ambedkar Hospital, Rohini, Delhi 110085, India \\ Correspondence should be addressed to Renu Gur; renugur@hotmail.com
}

Received 31 August 2015; Accepted 29 September 2015

Academic Editor: Zia U. Khan

Copyright (C) 2015 Shalini Dewan Duggal et al. This is an open access article distributed under the Creative Commons Attribution License, which permits unrestricted use, distribution, and reproduction in any medium, provided the original work is properly cited.

Resurgence of nonalbicans Candida spp. was observed thrice at the same location in our hospital over a period of four years. In two of these outbreaks it was identified up to the molecular level as Candida krusei. This fungus was traced to some environmental source in all three episodes. Prompt infection control measures were initiated which helped to control the outbreak every time. To the best of our knowledge, this is the first series of recurring Candida krusei infections at the same site in a hospital with successful control of each episode.

\section{Introduction}

Candida is the fourth leading cause of blood stream infections in hospitalized patients, with an associated mortality of $40-$ $50 \%$ [1]. Outbreaks of candidemia have been linked with contaminated milk bottles, parenteral nutrition, glycerine suppositories, contaminated intravenous fluids, syringe reutilization, health care worker (HCW) hand-colonization, and long term indwelling vascular devices [2]. It has been recognized as a difficult to treat fungal pathogen due to fluconazole resistance and decreased susceptibility to flucytosine and amphotericin B [2].

We present a report in which resurgence of nonalbicans Candida spp. was observed thrice at the same place over a period of four years after successful control each time. It was identified as the same strain of Candida krusei in the second and third outbreaks. In all the outbreaks the source could be traced and immediate control was achieved.

\section{Methods}

The outbreaks took place in September 2011, May 2013, and October 2014 in the neonatal ICU of our tertiary care hospital. Blood culture samples were processed by standard laboratory procedures. Cultures yielding growth of yeast like organisms were subjected to morphological identification on corn meal agar, germ tube test, and sugar assimilation test (SAT) by $4 \%$ carbohydrate discs (HiMedia, India) on yeast nitrogen base agar. Antifungal susceptibility testing (AFST) was done by broth microdilution as per CLSI Document M27-A3 [3]. C. krusei ATCC 6258 was used as standard strain. For molecular analysis genomic DNA from Candida krusei isolates was subjected to RAPD analysis using M13 Primer ( $5^{\prime}$ GAGGGTGGCGGTCT3 ${ }^{\prime}$ ). The reactions were performed in a final volume of $50 \mu \mathrm{L}$ with $30 \mathrm{ng}$ of Candida genomic DNA, $1 \mu \mathrm{L}$ Primer (1x sigma), $1.32 \mu \mathrm{L}$ Taq DNA polymerase (Bangalore Genei) $\left(3 \mathrm{U} / \mu \mathrm{L}\right.$ ), and $5 \mu \mathrm{L} \mathrm{MgCl}_{2}$ buffer (provided by Bangalore Genei with Taq DNA polymerase). The amplification was performed for ten cycles at low stringency, $95^{\circ} \mathrm{C}-3$ minutes and $95^{\circ} \mathrm{C}-1$ minute (denaturation), $35^{\circ} \mathrm{C}-$ 1 minute (annealing), and $72^{\circ} \mathrm{C}-1$ minute (extension) and for 30 cycles at high stringency, followed by $95^{\circ} \mathrm{C}-1$ minute (denaturation), $55^{\circ} \mathrm{C}-1$ minute (annealing), $72^{\circ} \mathrm{C}-1$ minute (extension), and $72^{\circ} \mathrm{C}-5$ minutes (final extension). The amplification products were separated on $1.4 \%$ agarose gel and stained by ethidium bromide at a concentration of 


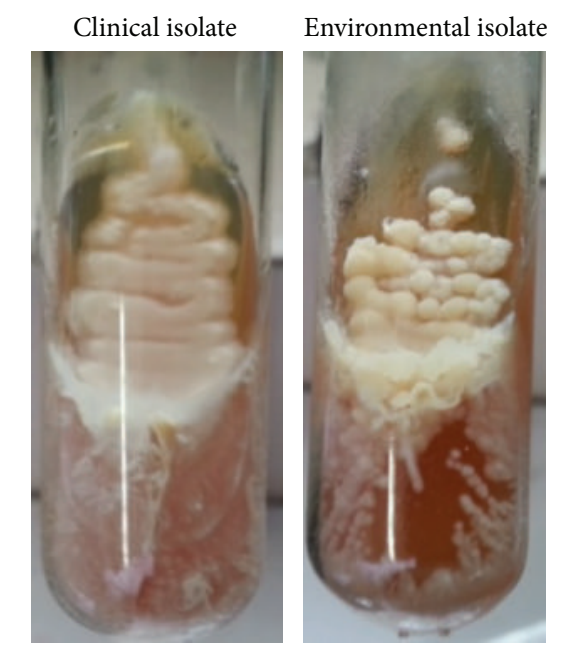

FIGURE 1: Growth on Sabouraud dextrose agar.

$10 \mathrm{mg} / \mathrm{mL}$ stock to a final concentration of $0.1 \mu \mathrm{g} / \mathrm{mL}$ in $1 X$ TBE (Tris-Borate-EDTA) for 5 hours at $3 \mathrm{~V} / \mathrm{cm}$ and observed under UV light (Gel Doc) [4].

A case definition was established for patients who were likely to have been exposed during this time period having similar risk factors and location. This included any neonate admitted in the neonatal ICU and presenting with signs of infection. Case control study was undertaken to establish risk factors for infection and to help elucidate potential source of contamination. The hospital authorities were alerted and the suspected samples and fluids were sent to Department of Microbiology for culture. Antifungal susceptibility patterns were reviewed followed by molecular analysis to establish the relatedness of suspected organisms. A thorough review of potential breaches in infection control practices in the ICU and at the point of infusate delivery was done. Cultures of the potential point source contaminants in the environment was performed, including intravenous medications administered to patients and processed likewise.

\section{Results}

In the first outbreak, the isolates were identified as nonalbicans Candida based on colony characteristics, morphology, and negative germ tube test (unpublished data). Further speciation, antifungal susceptibility, and molecular characterization could not be done. In the second outbreak, seven blood culture samples from patients in the neonatal ICU revealed growth of Candida krusei [5]. After 18 months of successful control, Candida krusei was isolated again from four patients in the neonatal ICU. All the positive samples were from neonates who had been admitted to the ICU for more than 72 hours.

3.1. Characterization of the Isolates. The isolates from patients and the environmental samples in all the three outbreaks showed negative germ tube test and morphology consistent with Candida krusei on corn meal agar. The colonies were

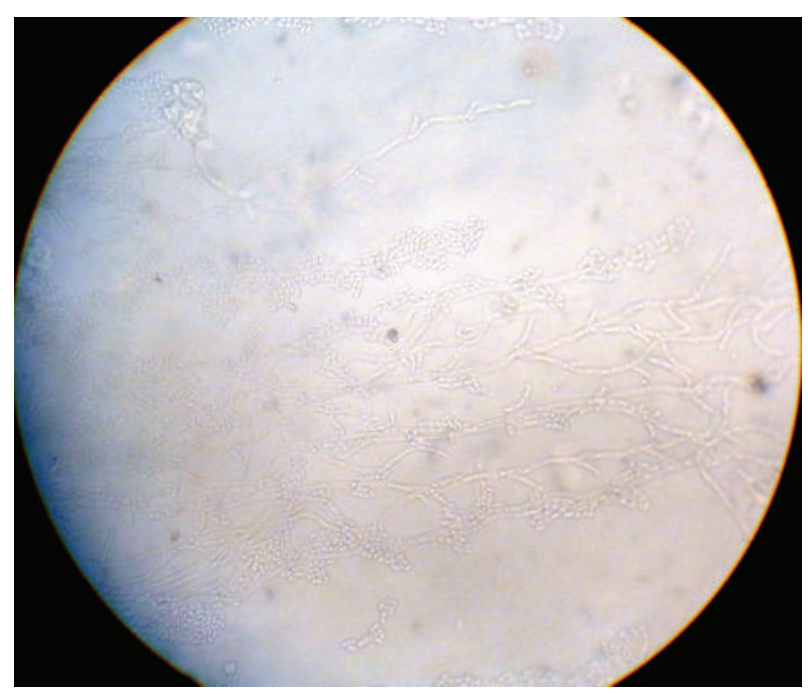

FIGURE 2: Growth on cornmeal agar 100x.

white to cream colored, smooth, and glabrous on Sabouraud's dextrose agar. The environmental isolate obtained from the suction bottle had a rough and rugose surface compared to the clinical isolates (Figure 1). Microscopically, small elongated to ovoid budding yeast-like cells, $2-3 \times 4-10 \mathrm{um}$ in size, were seen. Dalmau plate culture on cornmeal agar after 72 hours of incubation at $25^{\circ} \mathrm{C}$ showed abundant long, wavy, branched pseudohyphae with elongated to ovoid blastoconidia in verticillate branches; chlamydospores were not seen (Figure 2). Sugar assimilation test and further speciation of the nonalbicans Candida were done for isolates in the second and third outbreaks. They were positive for dextrose but negative for lactose, sucrose, inositol, dulcitol, trehalose, maltose, mellibose, cellobiose, galactose, and xylose.

3.2. Antifungal Susceptibility Testing. All C. krusei isolates exhibited similar pattern of antifungal susceptibility. They were resistant to fluconazole but susceptible to amphotericin $B$, caspofungin, and micafungin. Antifungal therapy was started with amphotericin B $1 \mathrm{mg} / \mathrm{kg} /$ day intravenously for 2 weeks.

3.3. Molecular Analysis. Relatedness among the C. krusei isolates was established after matching the RAPD (Rapid Amplified Polymorphic DNA Analysis) profiles. RAPD pattern of isolates showed similar band patterns of Candida krusei using M13 Primer in the latter two outbreaks (Figure 3).

3.4. Investigation of Outbreak and Infection Control. Relatedness among the clinical and the environmental isolates of Candida krusei was established by similar antifungal susceptibility and molecular profiles. The source of infection was found to be multielectrolyte dextrose solution in the first and second outbreaks and suction apparatus in the third outbreak. The brand of multielectrolyte dextrose solution was different in both outbreaks and in both cases yeast was isolated from unopened bottles also. They were immediately withdrawn from the ICU and replaced with another stock. 


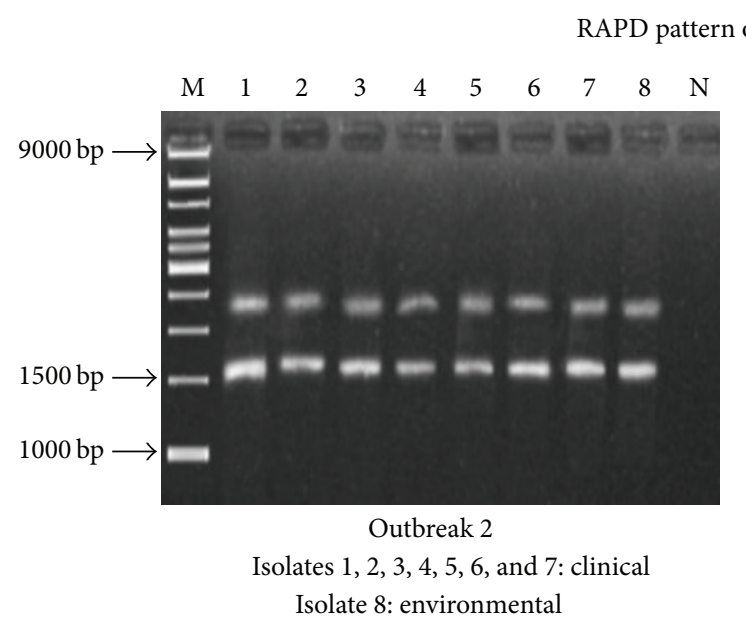

(a)

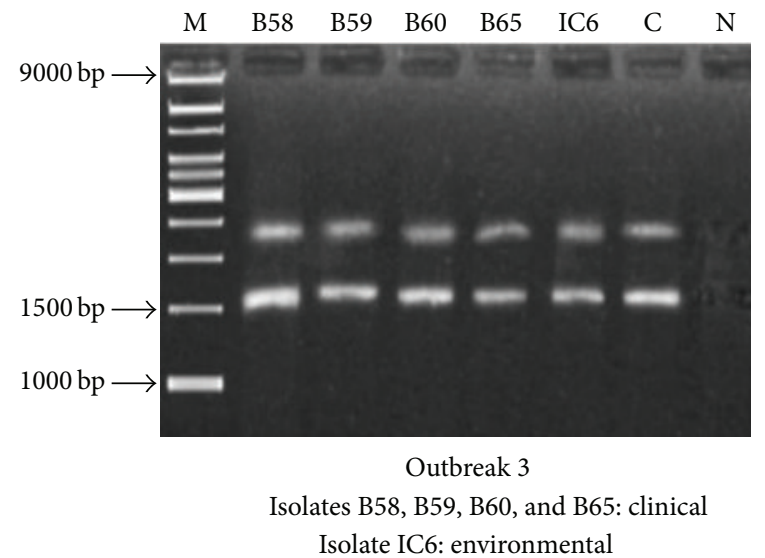

(b)

FIGURE 3: Clonality of isolates in outbreaks 2 and 3. (a) Random amplified polymorphic DNA analysis with M13 Primer; Lanes 1 to 8 represent the Candida krusei band pattern and Lane $\mathrm{M}$ represents the molecular weight markers $(1 \mathrm{~kb})$. Lane $\mathrm{N}$ represents the negative control. (b) Random amplified polymorphic DNA analysis with M13 Primer; Lanes B58 to IC6 represent the Candida krusei band pattern, Lane M represents the molecular weight markers $(1 \mathrm{~kb})$, Lane $\mathrm{C}$ represents the positive control, and Lane $\mathrm{N}$ represents the negative control.

The suction apparatus was properly cleaned, scrubbed, and disinfected; and hand hygiene protocols were reinforced. Infection control surveillance activities were reinforced in the ICU and the health care staff was advised to keep a strict vigil on all the fluids administered. Regular surveillance culture of the environmental fluids and the environmental surfaces were done. No fungus was isolated during the intervening surveillance period.

Though the increase in virulence or pathogenicity was not tested in each episode of fungaemia, it was observed that morbidity and mortality were more in the last outbreak (Table 1). Also the fact that the yeast was recovered from an environmental surface to which the strain had adapted was appreciable.

\section{Discussion}

C. krusei has emerged as a notable pathogen, especially in compromised patient groups in nosocomial settings. Widespread use of triazoles in these patients has contributed to a selective increase in C. krusei infection [6].

4.1. Clinical Manifestations. Neonates with invasive Candida infections usually present with nonspecific signs of infection. There may be temperature and glucose instability, respiratory distress, increase in oxygen requirements, necrotizing enterocolitis (NEC), feeding difficulties, lethargy, abdominal distension, and vomiting. It is difficult to ascertain whether the pathogen is fungus or bacteria, leading to delay in starting the appropriate treatment. There is an inverse relationship between gestational age and the acquisition of fungal sepsis. It has been reported that fungal sepsis is more common if the patient's gestational age is $<25$ weeks as seen among ELBW (extremely low birth weight) and VLBW (very low birth weight) groups [7]. In our study, multiple risk factors were present in the affected neonates including lower Apgar score and low birth weight.

4.2. Laboratory Investigations. Laboratory parameters like high C-reactive protein and thrombocytopenia are suggestive of septicaemia but positive blood culture is the gold standard for diagnosis. Even if a single yeast cell is visualized in gram-stained smear of a positive blood culture, it should be enough to alert the microbiologist and clinicians of a possible candidemia. Hence prompt treatment with amphotericin B should begin pending the yeast identification and susceptibility results. Candida krusei can be identified by negative germ tube test and characteristic colony morphology on corn meal and chromogenic agar media. Glucose is fermented as well as assimilated. Lactose, sucrose, galactose, maltose, and trehalose are neither fermented nor assimilated [8]. This could explain its persistence and growth in the multielectrolyte dextrose solution.

4.3. Virulence Factors. These include adherence to host cells, production of phospholipase, proteinase, and formation of hyphae. Few studies have been conducted to understand the various factors of Candida krusei in man and laboratory animals. Cytopathic effects of various Candida spp. have been studied in cell cultures. C. krusei, C. kefyr, and C. parapsilosis can destroy cultured mouse renal epithelial cells in 48$72 \mathrm{~h}$, whereas the relatively more pathogenic C. albicans, C. tropicalis, and C. stellatoidea induce degenerative changes rapidly and destroy the cultures in a much shorter period of $24 \mathrm{~h}$ [9]. Howlett determined the pathogenicity of C. krusei by an in vitro organ culture system comprising the dorsal tongue mucosa of neonatal Sprague Dawley rats. In the tissues infected with C. krusei, the fungus grew in both the yeast and mycelial phases but generally showed less invasiveness than C. albicans or C. tropicalis [10]. Cell-surface hydrophobicity 
TABLE 1: Differential characteristics in three successive outbreaks.

\begin{tabular}{|c|c|c|c|}
\hline $\begin{array}{l}\text { Characteristic } \\
\text { features }\end{array}$ & Outbreak 1 & Outbreak $2[5]$ & Outbreak 3 \\
\hline Causative agent & Candida nonalbicans & Candida krusei & Candida krusei \\
\hline Duration of outbreak & 2 days & 11 days & 10 days \\
\hline $\begin{array}{l}\text { Number of affected } \\
\text { neonates }\end{array}$ & 2 & 7 & 4 \\
\hline $\begin{array}{l}\text { Gestational age at } \\
\text { delivery }\end{array}$ & $\begin{array}{l}28 \text { weeks }(1) \\
30 \text { weeks (1) }\end{array}$ & $\begin{array}{l}28 \text { weeks (5) } \\
30 \text { weeks (1) } \\
36 \text { weeks (1) }\end{array}$ & $\begin{array}{l}26 \text { weeks (1) } \\
28 \text { weeks (1) } \\
37 \text { weeks (2) }\end{array}$ \\
\hline Host factors & $\begin{array}{l}\text { Prematurity, low birth } \\
\text { weight, asphyxia, and } \\
\text { TPN }\end{array}$ & $\begin{array}{c}\text { Prematurity, asphyxia, low } \\
\text { birth weight, IUGR, and } \\
\text { TPN }\end{array}$ & $\begin{array}{l}\text { VLBW, TPN, Apnea of } \\
\text { prematurity, HIE III, and } \\
\text { meconium stained liquor }\end{array}$ \\
\hline $\begin{array}{l}\text { Susceptible } \\
\text { antifungals }\end{array}$ & $\begin{array}{l}\text { Not tested, but patients } \\
\text { responded after } \\
\text { treatment with } \\
\text { amphotericin B }\end{array}$ & $\begin{array}{c}\text { Amphotericin } \mathrm{B}, \\
\text { caspofungin, micafungin, } \\
\text { anidulafungin }\end{array}$ & $\begin{array}{l}\text { Amphotericin B, caspofungin, } \\
\text { micafungin, and posaconazole }\end{array}$ \\
\hline Resistant antifungals & Not tested & Fluconazole & Fluconazole, flucytosine \\
\hline Outcome & No attributable mortality & No attributable mortality & One recovered, three expired \\
\hline
\end{tabular}

together with adherence may have clinical implications in fungal infections related to plastic devices such as implants and catheters. A study on 20 oral isolates of C. krusei showed 5 times greater hydrophobicity with biphasic assay system compared to C. albicans isolates. On polyvinyl chloride catheter disks C. krusei produced the most extensive biofilm [6].

4.4. Antifungal Therapy. The antifungals effective against $C$. krusei include amphotericin B and echinocandins. These should be continued for two weeks after documented clearance of Candida from the blood stream [11]. Amphotericin B disrupts the fungal cell membrane and kills the fungus while echinocandins act at fungal cell wall by irreversibly inhibiting $(1,3)$-a-D-glucan synthase. C. krusei isolates are intrinsically resistant to fluconazole as seen among our isolates also. Voriconazole may remain effective due to more efficient binding to the cytochrome P-450 isoenzyme. Resistance to azoles may develop due to alteration in the target enzyme, 14ademethylase, or its inhibition by deficiency of C5 desaturase enzyme [12]. This leads to accumulation of C14 methylated sterols and disrupt membrane structure. Another mechanism is decreased drug accumulation, mediated by either diminished uptake or increased efflux of the drug. Decreased susceptibility to amphotericin B and flucytosine has been reported in some $C$. krusei isolates. Hence susceptibility testing of C. krusei is warranted to help guide therapeutic decisions. Recovery from candidemia is defined as resolution of all clinical manifestations and documented clearance 2 weeks after therapy [13].

Since C. krusei is present in the environment, potential environmental sources of infection must be screened when this isolate grows in culture from sterile sites. Fortunately, in all these outbreaks, finding a source helped to effectively curb the outbreak in time. However, during the intervening periods, we could never isolate Candida from any of the routine surveillance cultures. Reappearance of this fungus despite stringent infection control in the affected area of the hospital remains an enigma. Though we could not speculate the exact reason for their resurgence, it can be said that these outbreaks usually occur when sterilization, disinfection, or other infection control practices are compromised. It may indicate an inanimate shelter including dextrose fluids or hospital environment niche where it can remain dormant over prolonged periods till an opportunity strikes.

Though an environmental source was always traced, we feel that cultures to identify fungal carriage on the hands of health care workers could have been done to find sustenance of this fungus during the interoutbreak periods. We also feel that dedicated trained health care staff posted in intensive care units should not be changed frequently. Training schedules should be intensified, especially for the staff in high risk areas, and they should be sensitized to hand hygiene and other infection control practices in their work area. Hand hygiene protocols should also be followed by the relatives, especially mothers of neonates who frequently handle them for feeding or fondling. Also intravenous fluids should be in smaller pack sizes for the neonates to be consumed during single use. Though the bottles are received as sealed packs, breaches in quality control practices starting from the point of manufacturing to the distributer, supplier, and consumer cannot be ruled out.

Based on literature search, we could find five articles in the medical literature that report six isolated cases and an outbreak of seven cases of $C$. krusei fungemia amongst neonates (Table 2) [14-18]. There are no previous reports of repeated isolation of a fungal pathogen from the same area. This is the first study reporting on recurring Candida krusei outbreaks from a tertiary care hospital in Delhi, India. 
TABLE 2: Cases of Candida krusei blood stream infections cited in the literature.

\begin{tabular}{|c|c|c|c|c|c|c|}
\hline References & $\begin{array}{c}\text { Number of } \\
\text { patients }\end{array}$ & $\begin{array}{l}\text { Gestational } \\
\text { age at birth }\end{array}$ & Risk factors & $\begin{array}{l}\text { Culture } \\
\text { origin }\end{array}$ & Therapy & Outcome \\
\hline $\begin{array}{l}\text { Wanjari et al., } 2008 \\
\text { [14] }\end{array}$ & 01 & $28 \mathrm{wks}$ & $\begin{array}{l}\text { Prematurity, congenital } \\
\text { tuberculosis }\end{array}$ & Gastric blood & $\begin{array}{l}\text { Fluconazole, } \\
\text { amphotericin B }\end{array}$ & Recovered \\
\hline $\begin{array}{l}\text { Patted et al., } 2009 \\
\text { [15] }\end{array}$ & 01 & $34 \mathrm{wks}$ & $\begin{array}{l}\text { Prematurity, broad } \\
\text { spectrum antibiotics }\end{array}$ & $\begin{array}{c}\text { Right } \\
\text { ventricular } \\
\text { mass }\end{array}$ & Not mentioned & Expired \\
\hline $\begin{array}{l}\text { Natale et al., } 2009 \\
{[16]}\end{array}$ & 01 & $26 \mathrm{wks}$ & $\begin{array}{c}\text { Prematurity, } \\
\text { thrombocytopenia, and } \\
\text { fluconazole prophylaxis }\end{array}$ & $\begin{array}{l}\text { Peripheral } \\
\text { blood culture }\end{array}$ & $\begin{array}{l}\text { Amphotericin B, } \\
\text { caspofungin }\end{array}$ & Recovered \\
\hline $\begin{array}{l}\text { Amaral-Lopes and } \\
\text { Moura, } 2012 \text { [17] }\end{array}$ & 03 & $\begin{array}{l}25 \mathrm{wks} \\
31 \mathrm{wks} \\
29 \mathrm{wks}\end{array}$ & $\begin{array}{c}\text { Premature } \\
\text { pneumoperitoneum } \\
\text { abdominal distension, } \\
\text { and hyperglycemia }\end{array}$ & Blood culture & $\begin{array}{l}\text { Liposomal amphotericin } \\
\text { B }\end{array}$ & Recovered \\
\hline $\begin{array}{l}\text { Handrick et al., } \\
1989 \text { [18] }\end{array}$ & 07 & Full term & $\begin{array}{c}\text { Perinatal problems (Not } \\
\text { specified) }\end{array}$ & Blood culture & $\begin{array}{l}\text { Miconazole/ } \\
\text { ketoconazole }\end{array}$ & Recovered \\
\hline $\begin{array}{l}\text { Rongpharpi et al., } \\
2014 \text { [5] }\end{array}$ & 07 & $28-36$ wks & $\begin{array}{l}\text { Preterm, low birth } \\
\text { weight }\end{array}$ & Blood culture & Amphotericin B & Recovered \\
\hline
\end{tabular}

\section{Conclusion}

C. krusei is an uncommon cause of blood stream infections. Detection of simultaneous episodes in the neonatal ICU of our hospital led us to consider the possibility of an outbreak, which was further confirmed after environmental sampling. Continued infection control surveillance activities coupled with molecular analysis of the source and clinical isolates can bring out important information relating to nosocomial infections. Hence recognition, diagnosis, and prompt action are key to infection control. Breaches in infection control protocols pave the way for impending outbreaks but timely intervention including source tracing is the key to effective control.

\section{Conflict of Interests}

The authors declare that there is no conflict of interests regarding the publication of this paper.

\section{References}

[1] M. A. Pfaller and D. J. Diekema, "Epidemiology of invasive candidiasis: a persistent public health problem," Clinical Microbiology Reviews, vol. 20, no. 1, pp. 133-163, 2007.

[2] C. A. DiazGranados, A. Martinez, C. Deaza, and S. Valderrama, "An outbreak of Candida spp. bloodstream infection in a tertiary care center in Bogotá, Colombia," The Brazilian Journal of Infectious Diseases, vol. 12, no. 5, pp. 390-394, 2008.

[3] Clinical and Laboratory Standards Institute, CLSI Reference Method for Broth Dilution Antifungal Susceptibility Testing of Yeasts, CLSI Document M27-A3, Clinical and Laboratory Standards Institute, Wayne, Pa, USA, 3rd edition, 2008.

[4] G. Schonian, O. Meusel, H.-J. Tietz et al., "Identification of clinical strains of Candida albicans by DNA fingerprinting with the polymerase chain reaction," Mycoses, vol. 36, no. 5-6, pp. 171179, 1993.
[5] S. R. Rongpharpi, R. Gur, S. Duggal et al., "Candida krusei fungemia in 7 neonates: clonality tracked to an infusate," American Journal of Infection Control, vol. 42, no. 11, pp. 12471248, 2014.

[6] Y. H. Samaranayake and L. P. Samaranayake, "Candida krusei: biology, epidemiology, pathogenicity and clinical manifestations of an emerging pathogen," Journal of Medical Microbiology, vol. 41, no. 5, pp. 295-310, 1994.

[7] D. Kaufman and K. D. Fairchild, "Clinical microbiology of bacterial and fungal sepsis in very-low-birth-weight infants," Clinical Microbiology Reviews, vol. 17, no. 3, pp. 638-680, 2004.

[8] V. Manjunath, G. S. Vidya, A. Sharma, M. R. Prakash, and Murugesh, "Speciation of Candida by Hicrome agar and Sugar assimilation test in both hiv infected and non infected patients," International Journal of Biological and Medical Research, vol. 3, no. 2, pp. 1778-1782, 2012.

[9] R. Hurley and V. C. Stanley, "Cytopathic effects of pathogenic a non-pathogenic species of Candida on cultured mouse epithelial cells: relation to the growth rate and morphology of the fungi," Journal of Medical Microbiology, vol. 2, no. 1, pp. 63-74, 1969.

[10] J. A. Howlett, "The infection of rat tongue mucosa in vitro with 5 species of Candida," Journal of Medical Microbiology, vol. 9, no. 3, pp. 309-316, 1976.

[11] P. G. Pappas, C. A. Kaufman, D. Andes et al., "Clinical practice guidelines for the management of candidiasis: update by Infectious Diseases Society of America," Clinical Infectious Diseases, vol. 48, no. 5, pp. 503-528, 2009.

[12] A. S. Orozco, L. M. Higginbotham, C. A. Hitchcock et al., "Mechanism of fluconazole resistance in Candida krusei," Antimicrobial Agents and Chemotherapy, vol. 42, no. 10, pp. 2645-2649, 1998.

[13] L. A. Mermel, M. Allon, E. Bouza et al., "Clinical practice guidelines for the diagnosis and management of intravascular catheter-related infection: 2009 update by the infectious diseases society of America," Clinical Infectious Diseases, vol. 49, no. 1, pp. 1-45, 2009.

[14] K. Wanjari, M. Mathur, V. P. Baradkar, and S. Kumar, "Congenital tuberculosis with candidal sepsis in a neonate," Indian 
Journal of Pathology and Microbiology, vol. 51, no. 2, pp. 289291, 2008.

[15] S. V. Patted, P. C. Halkati, S. T. Yavagal, and R. Patil, “Candida krusei infection presenting as a right ventricular mass in a two month old Infant," Annals of Pediatric Cardiology, vol. 2, no. 2, pp. 170-172, 2009.

[16] F. Natale, A. Castronovo, D. Regoli, M. De Curtis, and P. Manzoni, "Successful treatment with caspofungin of refractory candida krusei candidemia in a very low birth weight preterm infant," Pediatric Infectious Disease Journal, vol. 28, no. 5, p. 452, 2009.

[17] S. Amaral-Lopes and A. Moura, "Neonatal fungal sepsis by Candida krusei: a report of three cases and a literature review," Medical Mycology Case Reports, vol. 1, no. 1, pp. 24-26, 2012.

[18] W. Handrick, C. Schonmborn, F. B. Spencer, and D. Huckel, "Infections due to Candida krusei in neonates," Paediatric und Padologie, vol. 24, pp. 289-295, 1989. 

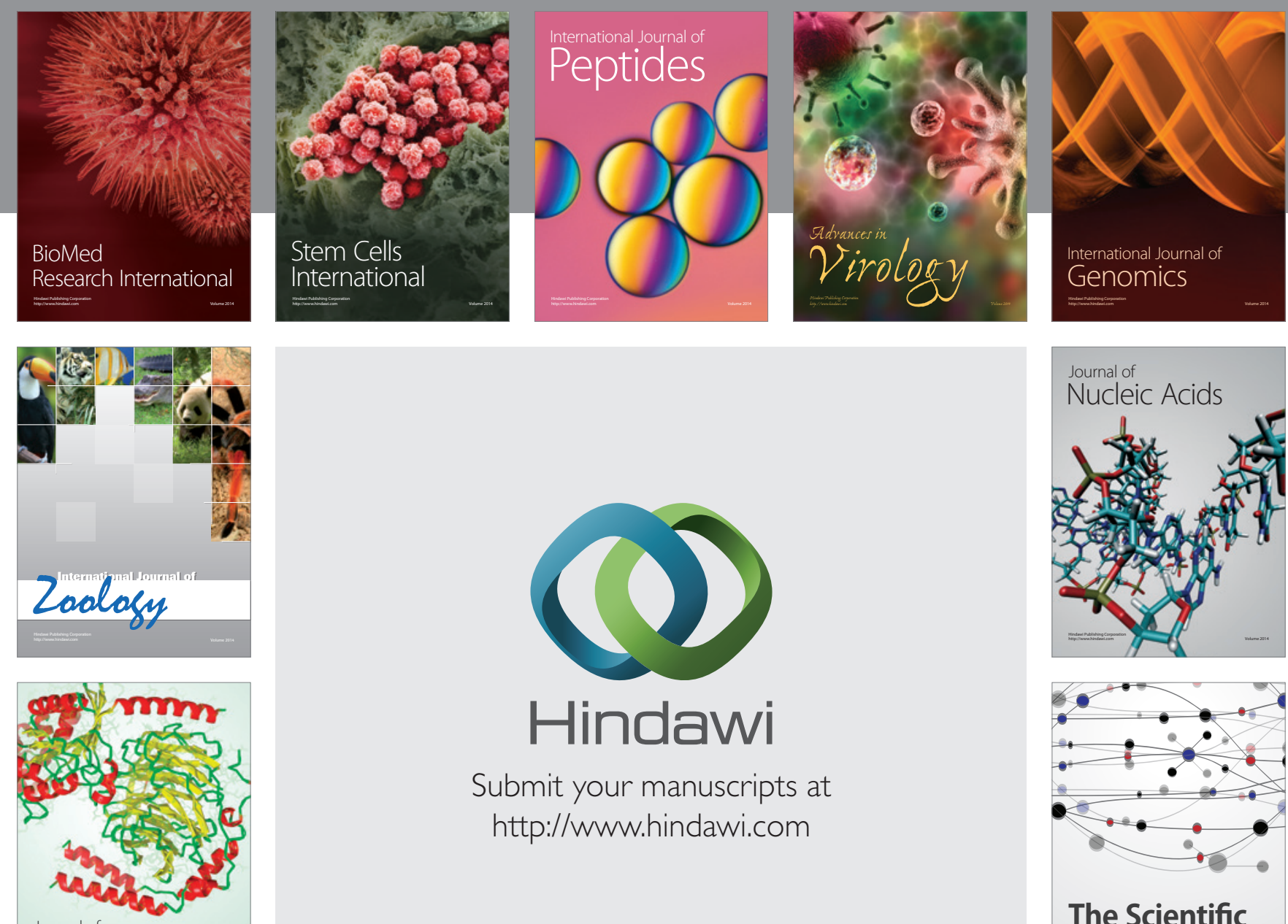

Submit your manuscripts at

http://www.hindawi.com

Journal of
Signal Transduction
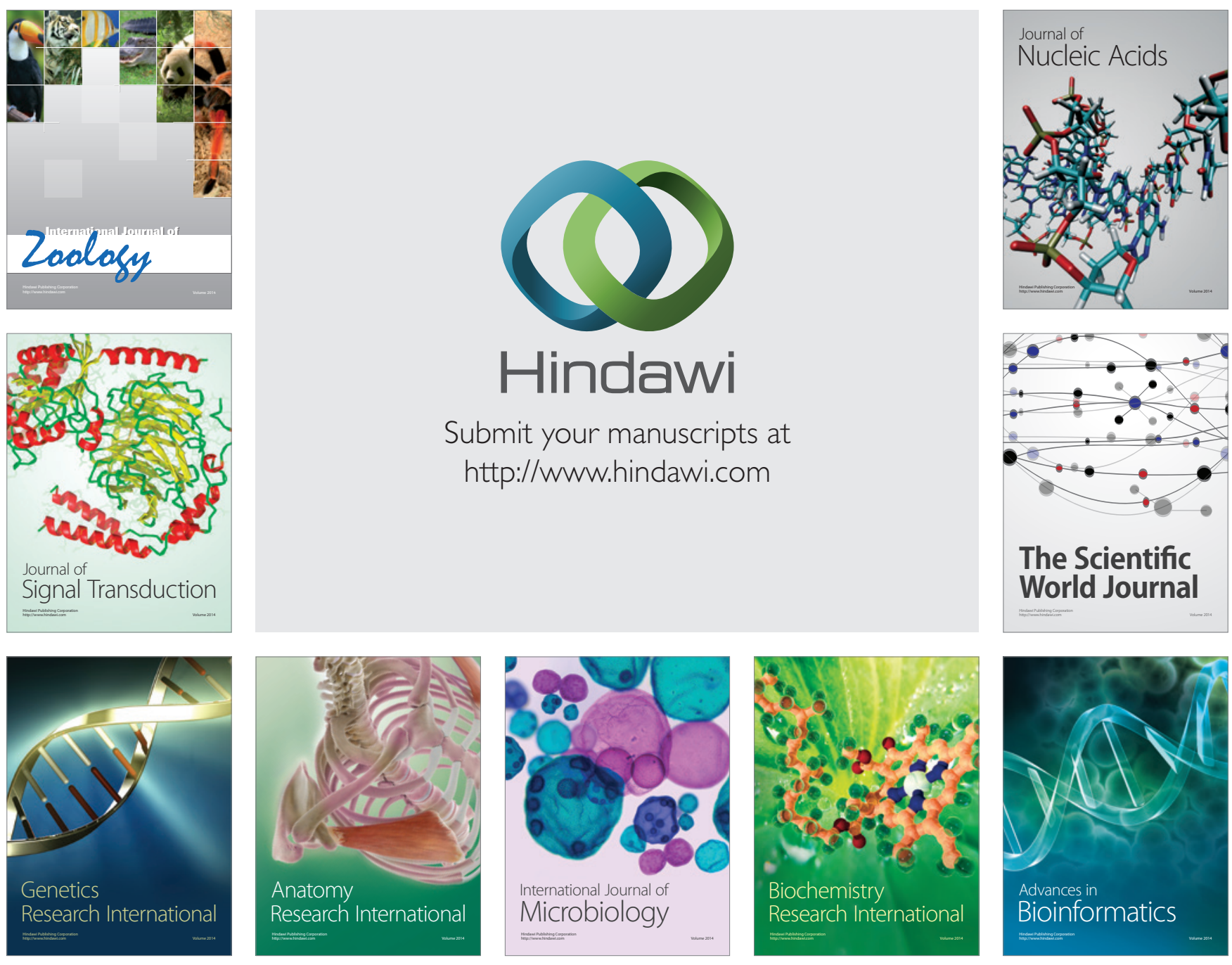

The Scientific World Journal
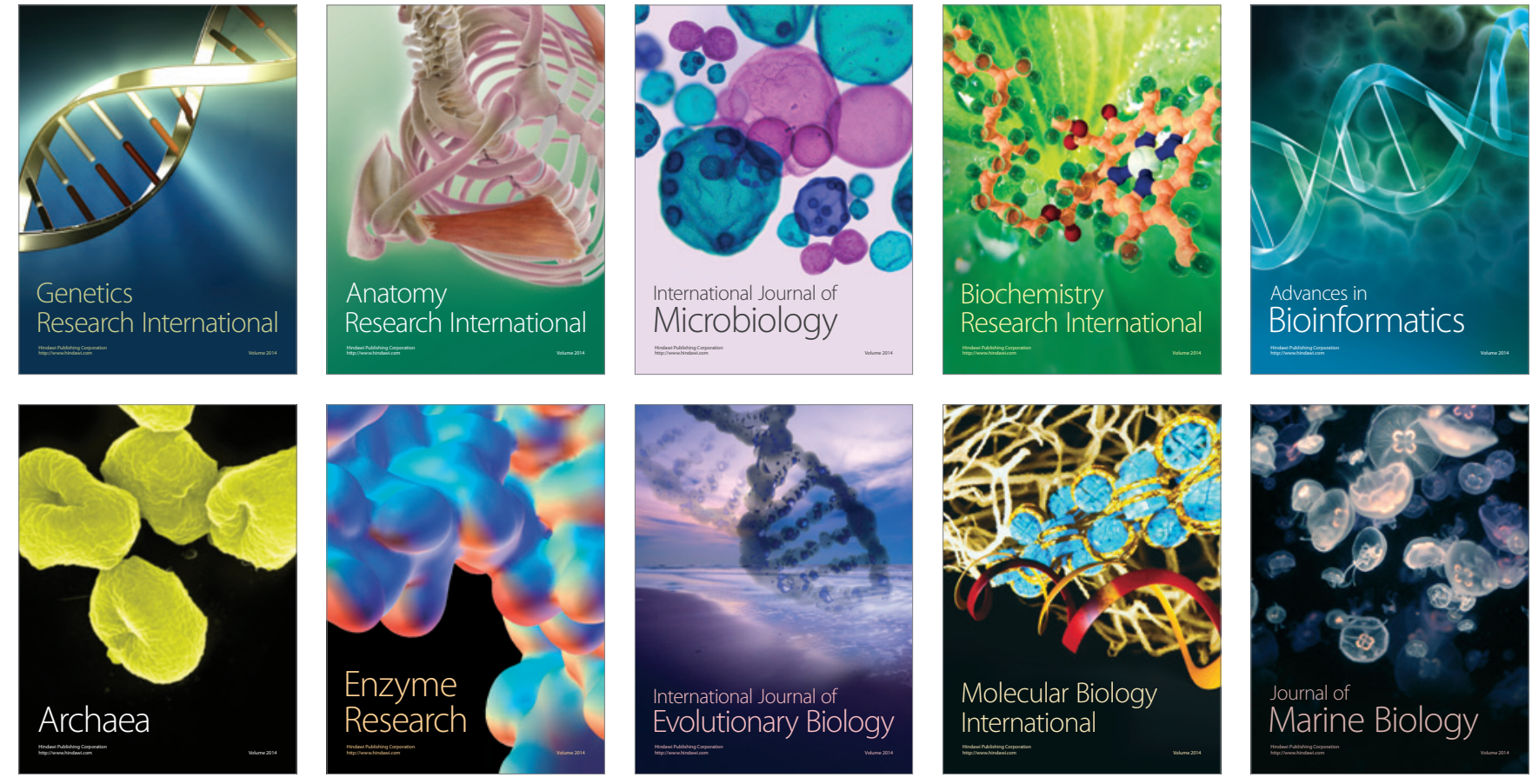